\title{
Pengaruh pertumbuhan penduduk, inflasi, investasi, upah minimum dan kesempatan kerja terhadap pengangguran di Kota Jambi
}

\author{
Aditya Surya Chandra*; Yulmardi ; Erfit \\ Prodi Magister Ilmu Ekonomi, Program Pascasarjana, Universitas Jambi \\ *E-mail korespodensi: aschandra22@gmail.com
}

\begin{abstract}
This study aims to: 1) To analyze the development of population growth, inflation, investment, minimum wages, job opportunities and unemployment in Jambi City during 2001-2017., 2) To determine and analyze the effects of population growth, inflation, investment, minimum wages and job opportunities for unemployment in Jambi City during 2001-2017. Based on the research results, it can be concluded that the structural equation I show that the development of population growth, inflation, investment, minimum wages, and job opportunities has fluctuated every year, as well as the unemployment variable which fluctuates annually. Based on the results of the t-test on multiple linear regression, it can be concluded that only the job opportunity variable affects unemployment because the probability is less than 0.05.
\end{abstract}

Keywords: Population growth, Inflation, Investment, Minimum wages, Employment opportunities, Unemployment

\begin{abstract}
Abstrak
Penelitian ini bertujuan untuk: 1) Untuk menganalisis perkembangan pertumbuhan penduduk, inflasi, investasi, upah minimum, kesempatan kerja dan pengangguran di Kota Jambi selama tahun 2001-2017., 2) Untuk mengetahui dan menganalisis pengaruh pertumbuhan penduduk, inflasi, investasi, upah minimum dan kesempatan kerja terhadap pengangguran di Kota Jambi selama tahun 2001-2017. Berdasarkan hasil penelitian dapat disimpulkan persamaan struktural I menunjukkan bahwa perkembangan pertumbuhan penduduk, inflasi, investasi, upah minimum dan kesempatan kerja mengalami fluktuasi setiap tahunnya, begitu juga dengan variabel pengangguran yang setiap tahunnya mengalami fluktuasi. Berdasarkan hasil uji $\mathrm{t}$ pada regresi linier berganda dapat disimpulkan bahwa yang berpengaruh terhadap penganguran hanya variabel kesempatan kerja karena probabilitanya lebih kecil dari 0,05 .
\end{abstract}

Kata kunci : Pertumbuhan penduduk, Inflasi, Investasi, Upah minimum, Kesempatan kerja, Pengangguran.

\section{PENDAHULUAN}

Pembangunan adalah suatu proses perubahan menuju ke arah yang lebih baik dan terus menerus untuk mencapai tujuan yakni mewujudkan masyarakat Indonesia yang berkeadilan, berdaya saing, maju, dan sejahtera dalam wadah Negara Kesatuan Republik Indonesia. Pembangunan harus diarahkan sedemikian rupa sehingga setiap tahap semakin 
mendekati tujuan. Hidup layak merupakan hak asasi manusia yang diakui secara universal. Konstitusi Indonesia UUD'45, secara eksplisit mengakui hal itu dengan mengamanatkan bahwa tugas pokok pemerintah Republik Indonesia adalah "memajukan kesejahteraan umum, mencerdaskan kehidupan bangsa serta mewujudkan suatu keadilan sosial bagi seluruh rakyat Indonesia". Hal itu berarti, hidup bebas dari kemiskinan dan pengangguran atau menikmati kehidupan yang layak merupakan hak asasi setiap warga negara adalah tugas pemerintah untuk menjamin terwujudnya hal itu. Pembangunan nasional pada dasarnya ialah meningkatkan kesejahteraan umum yang adil dan merata bagi seluruh rakyat Indonesia. Dengan demikian pengentasan kemiskinan dan pengurangan pengangguran merupakan prioritas utama pembangunan.

Salah satu tujuan dari pembangunan ekonomi adalah mengatasi pengangguran. Pengangguran terjadi karena ketidakseimbangan antara jumlah angkatan kerja dengan jumlah kesempatan kerja yang tersedia. Menurut Keynes perekonomian selalu menghadapi masalah pengangguran dan penggunaan tenaga kerja penuh jarang berlaku (Sukirno, 2013).

Pengangguran adalah masalah makroekonomi yang mempengaruhi manusia secara langsung dan merupakan yang paling berat. Kebanyakan orang kehilangaan pekerjaan berarti penurunan standar kehidupan dan rekaman psikologis. Jadi tidaklah mengejutkan jika pengangguran menjadi topik yang sering dibicarakan dalam perdebatan politik dan para politis sering mengklaim bahwa kebijakan yang mereka tawarkan akan membantu menciptakan lapangan kerja (Mankiw, 2006).

Pengangguran (unemployment) merupakan kenyataan yang dihadapi tidak saja oleh negara-negara sedang berkembang (developing countries), akan tetapi juga negaranegara yang sudah maju (developed countries). Secara umum, pengangguran didefinisikan sebagai suatu keadaan dimana seseorang yang tergolong dalam kategori angkatan kerja (labor force) tidak memiliki pekerjaan dan secara aktif sedang mencari pekerjaan. Seseorang yang tidak bekerja tetapi secara aktif mencari pekerjaan tidak dapat digolongkan sebagai penganggur. Selain itu pengangguran diartikan sebagai suatu keadaan dimana seseorang yang tergolong dalam angkatan kerja ingin mendapatkan pekerjaan belum dapat memperolehnya (Sukirno, 2013).

Pengangguran adalah adalah orang yang tidak bekerja dan yang 1) secara aktif mencari pekerjaan selama 4 (empat) minggu sebelumnya, atau 2) sedang menunggu dipanggil kembali suatu pekerjaan setelah diberhentikan, atau 3) sedang menunggu untuk melapor atas pekerjaan yang baru dalam jangka waktu 4 (empat) minggu (Dornbusch, dkk 2007). Pengangguran merupakan salah satu masalah utama dalam jangka pendek yang selalu dihadapi setiap negara. Karena itu, setiap perekonomian dan negara pasti menghadapi masalah pengangguran, yaitu pengangguran alamiah (natural rate of unemployment). Provinsi Jambi merupakan daerah dimana salah satu permasalahan yang dihadapi yaitu pengangguran

Berdasarkan data dari BPS mengenai jumlah pengangguran di kabupaten/kota di Provinsi Jambi selama tahun 2011 sampai tahun 2017 dimana setiap tahunnya jumlah pengangguran cenderung mengalami peningkatan. Untuk rata-rata jumlah pengangguran terbesar terjadi pada Kota Jambi dengan rata-rata realisasi jumlah pengangguran selama tujuh tahun terakhir sebesar 18.540 jiwa. Sedangkan rata-rata jumlah terendah terjadi di Kabupaten Tanjung Jabung Timur yaitu sebesar 2.386 jiwa. Selanjutnya rata-rata penurunan perkembangan jumlah pengangguran hanya terjadi di Kabupaten Tanjung 
Jabung Timur yaitu sebesar -7,92 persen, sementara kabupaten/kota lainnya yang ada di Provinsi Jambi mengalami peningkatan setiap tahunnya.

Pertumbuhan penduduk dari tahun ke tahun terus meningkat. Di sisi lain, peningkatan kemampuan ekonomi, baik pemerintah maupun swasta tidak secepat peningkatan pertumbuhan penduduk. Dengan kata lain, laju permintaan lapangan kerja tidak sebanding dengan laju penawaran lapangan kerja. Akibatnya, rentetan dampak negatif dari semakin tingginya pengangguran semakin meningkat.

Dalam bukunya, Keynes menyatakan bahwa penyebab terjadinya pengangguran, satu di antaranya terkait dengan penggunaan kapital sehingga masalah ketenagakerjaan tergantung pada jumlah pengeluaran (total expenditure) (Fusfeld,1993). Menurut keynes, pengangguran tidak dapat dihapuskan tetapi dapat dikurangi. Pengurangan pengangguran dapat dilakukan dengan memperluas kesempatan kerja dan untuk memperluas kesempatan kerja diperlukan modal, modal yang diperlukan adalah investasi.

Investasi bertujuan memaksimalkan output total pada satu titik waktu atau satu periode waktu. jumlah investasi yang terlaksana atau terealisasi sangat berperan terhadap penyerapan tenaga kerja dalam satu masyarakat dan kurangnya investasi akan menimbulkan pengangguran (Sukirno, 2004). Adanya investasi dalam masyarakat pertama-tama akan memberikan dan menambah kesempatan kerja sehingga pendapatan masyarakat pun bertambah.

Upah minimum merupakan salah satu faktor yang mempengaruhi tingkat pengangguran. Upah merupakan kompensasi yang diterima oleh satu unit kerja berupa jumlah uang yang dibayarkan. Upah tenaga kerja sangat penting untuk kedua belah pihak. Bagi pihak produsen, upah merupakan biaya produksi yang harus ditekan seefisien mungkin. Bagi pihak pekerja, upah merupakan sumber penghasilan bagi dirinya, keluarganya dan menjadi sumber pembelanjaan masyarakat. Tinggi rendahnya upah merupakan faktor penting yang menentukan taraf hidup masyarakat. semakin tinggi tingkat upah yang ditetapkan akan membawa pengaruh pada tingginya tingkat pengangguran yang terjadi” Kaufman dan Hotchkiss (1999). Kesimpulannya, semakin tinggi upah minimum maka pengangguran akan semakin meningkat.

Kesempatan kerja merupakan sebagai suatu keadaan dimana semua pekerja yang ingin bekerja pada suatu tingkat upah tertentu akan dengan mudah mendapat pekerjaan. (Sukirno, 2013). Kesempatan kerja mengandung pengertian lapangan pekerjaan dan kesempatan untuk bekerja, yang ada dari suatu kegiatan ekonomi (produksi). Dengan demikian kesempatan kerja adalah lapangan pekerjaan yang sudah diduduki dan masih lowong, sehingga semakin besar dan semakin luas kesempatan kerja tersedia maka semakin besar pengangguran dapat berkurang.

Berdasarkan teori diatas dapat diketahui adanya hubungan yang searah antara pertumbuhan penduduk, upah minimum dan kesempatan kerja dengan pengangguran serta adanya hubungan yang tidak searah antara inflasi dan investasi dengan pengangguran. Berdasarkan sumber yang diambil dari BPS Provinsi Jambi, Dinas Penanaman Modal dan Pelayanan Terpadu Satu Pintu (DPMPTSP) Kota Jambi, Bank Indonesia (2018) mengenai data pertumbuhan penduduk, inflasi, investasi, upah minimum kesempatan kerja dan pengangguran di Kota Jambi selama tahun 2001-2017. Pertumbuhan penduduk, inflasi, investasi, kesempatan kerja dan pengangguran selama tahun 2001-2017 mengalami naik turun hampir setiap tahunnya, sementara peningkatan upah minimum terus mengalami peningkatan setiap tahunnya. Pertumbuhan penduduk tahun 2001 sebesar 1,34 persen cenderung mengalami penurunan hingga tahun 2017 
menjadi sebesar 1,31 persen saja dan rata-rata selama tahun 2001-2017 sebesar 1,45 persen, inflasi tahun 2001 sebesar 7,58 persen cenderung mengalami penurunan hingga tahun 2017 menjadi sebesar 2,32 persen dengan rata-rata selama tahun 2001-2017 sebesar 5,73 persen, investasi pada tahun 2001 sebesar Rp. 876 milyar berkembang secara berfluktuasi namun cenderung mengalami penurunan hingga tahun 2017 investasi di Kota Jambi sebesar Rp. 2.978 milyar dengan rata-rata perkembangan selama tahun 2001-2017 sebesar 8,55 persen. Upah minimum terus mengalami peningkatan setiap tahunnya, pada tahun 2001 upah minimum di Kota Jambi sebesar Rp. 245 ribu terus meningkat hingga tahun 2017 menjadi sebesar Rp. 2.063 ribu dengan rata-rata perkembangan selama tahun 2001-2017 sebesar 14,36 persen. Kesempatan kerja di Kota Jambi tahun 2001 sebanyak 142 ribu orang dan cenderung meningkat setiap tahunnya hingga tahun 2017 menjadi sebanyak 268 ribu orang dengan rata-rata perkembangan selama tahun 2001-2017 sebesar 4,12 persen. Penganguran di Kota Jambi setiap tahunnya berfluktuasi namun cenderung menurun, pada tahun 2001 pengangguran di Kota Jambi sebesar 9.138 ribu orang hingga tahun 2017 penganguran menjadi sebanyak 15.754 ribu orang dengan rata-rata perkembangan selama tahun 2001-2017 sebesar 3,78 persen.

Berdasarkan fenomena diatas dapat menunjukkan bahwa pengganguran di Kota Jambi masih sangat tinggi dan fakta yang terjadi di Kota Jambi tidak sesuai dengan teori yang telah dikemukakan para ahli dan peneliti sebelumnya. Naik turunnya perkembangan pertumbuhan penduduk, inflasi, investasi, kesempatan kerja serta meningkatnya upah minimum setiap tahunnya tidak selalu mempengaruhi pengangguran di Kota Jambi. Untuk itu, penulis lebih lanjut akan menganalisis lebih jauh penelitian ini dalam bentuk tesis dengan judul "Pengaruh Pertumbuhan Penduduk, Inflasi, Investasi, Upah Minimum dan Kesempatan Kerja terhadap Pengangguran di Kota Jambi”.

\section{METODE}

\section{Analisis deskriptif}

Analisis deskriptif digunakan untuk mendeskripsikan perkembangan pertumbuhan penduduk, inflasi, investasi, upah minimum, kesempatan kerja dan pengangguran di Kota Jambi selama tahun 2001-2017.

\section{Analisis kuantitatif}

Analisis kuantitatif digunakan untuk menganalisis informasi kuantitatif (data yang dapat diukur, diuji, dan diinformasikan dalam bentuk persamaan, tabel dan sebagainya).

\section{Alat analisis}

Alat analisis yang digunakan untuk menyelesaikan permasalahan dalam penelitian ini adalah sebagai berikut :

Untuk menjawab tujuan pertama digunakan rumus berikut :

$$
\mathrm{Gx}=\frac{X_{t}-X_{t-1}}{X_{t-1}} \times 100
$$

Dengan menggunakan rumus diatas maka dapat dimasukkan variabel-variabel yang digunakan dalam penelitian ini guna untuk mengetahui bagaimana perkembangan pertumbuhan penduduk, inflasi, investasi, upah minimum, kesempatan kerja dan pengangguran di Kota Jambi. 
Adapun rumus perkembangan Pengangguran dalam penelitian ini adalah:

$$
\begin{aligned}
& G_{P G}=\frac{P G_{t}-P G_{t-1}}{P G_{t-1}} \times 100 \\
& G_{P P}=\frac{P P_{t}-P P_{t-1}}{P P_{t-1}} \times 100 \\
& G_{I N F}=\frac{I N F_{t}-I N F_{t-1}}{I N F_{t-1}} \times 100 \\
& G_{I N V}=\frac{I N V_{t}-I N V_{t-1}}{I N V_{t-1}} \times 100 \\
& G_{U M}=\frac{U M_{t}-U M_{t-1}}{U M_{t-1}} \times 100 \\
& G_{K K}=\frac{K K_{t}-K K_{t-1}}{K K_{t-1}} \times 100
\end{aligned}
$$

Dimana : $\quad G_{P G}=$ Perkembangan Pengangguran tahun 2001-2017

GPP $=$ Perkembangan Pertumbuhan penduduk tahun 2001- 2017

$\mathrm{G}_{\mathrm{INF}}=$ Perkembangan Inflasi tahun 2001-2017

$\mathrm{G}_{\mathrm{INV}}=$ Perkembangan Investasi tahun 2001-2017

$\mathrm{G}_{\mathrm{UM}}=$ Perkembangan Upah Minimum tahun 2001-2017

$\mathrm{G}_{\mathrm{KK}}=$ Perkembangan Kesempatan kerja tahun 2001-2017

$\mathrm{G}_{\mathrm{PG} 1}=$ Pengangguran tahun pertama

GP1 = Pertumbuhan penduduk tahun pertama

$\mathrm{G}_{\mathrm{INV} 1}=$ Investasi tahun pertama

$\mathrm{G}_{\mathrm{INF} 1}=$ Inflasi tahun pertama

GuM1 = Upah Minimum tahun pertama

$\mathrm{G}_{\mathrm{KK} 1}=$ Kesempatan Kerja tahun pertama

$\mathrm{G}_{\mathrm{PG}(\mathrm{t}-1)}=$ Pengangguran tahun sebelumnya

$\mathrm{G}_{\mathrm{PP}(\mathrm{t}-1)}=$ Pertumbuhan penduduk tahun sebelumnya

$\mathrm{G}_{\mathrm{INV}(\mathrm{t}-1)}=$ Investasu tahun sebelumnya

$\mathrm{G}_{\mathrm{INF}(\mathrm{t}-1)}=$ Inflasi tahun sebelumnya

$\mathrm{G}_{\mathrm{UM}(\mathrm{t}-1)}=\mathrm{Upah}$ minimum tahun sebelumnya

$\mathrm{G}_{\mathrm{KK}(\mathrm{t}-1)}=$ Kesempatan Kerja tahun sebelumnya

Untuk menjawab tujuan yang kedua, menggunakan rumus regresi Linier Berganda (Ariefianto,2011)yaitu :

$$
\mathrm{Y}=\beta_{0}+\beta_{1} \mathrm{X}_{1}+\beta_{2} \mathrm{X}_{2}+\beta_{3} \mathrm{X}_{3} \mathrm{X}_{2}+\beta_{4} \mathrm{X}_{4} \mathrm{X}_{2}+\beta_{5} \mathrm{X}_{5}+\mathrm{e}
$$

Dengan menggunakan persamaan regresi linier berganda diatas, maka disesuaikan dengan variabel yang akan di analisis. Adapun bentuk persamaan regresi linier berganda adalah :

$\mathrm{PG}=\beta_{0}+\beta_{1} \mathrm{PP}+\beta_{2} \mathrm{INF}+\beta_{3} \mathrm{INV}+\beta_{4} \mathrm{UM}+\beta_{5} \mathrm{KK}+\mathrm{e}$

Dimana :

$$
\begin{array}{ll}
\text { PG } & =\text { Pengangguran } \\
\text { PP } & =\text { Pertumbuhan Penduduk } \\
\text { INF } & =\text { Inflasi } \\
\text { INV } & =\text { Investasi } \\
\text { UM } & =\text { Upah Minimum } \\
\text { KK } & =\text { Kesempatan Kerja } \\
\beta_{1}, \beta_{2}, \beta_{3} & =\text { Koefisien Elastisitas } \\
\mathrm{e} & =\text { Standar error }
\end{array}
$$




\section{HASIL DAN PEMBAHASAN}

\section{Perkembangan Pertumbuhan Penduduk}

Jumlah penduduk yang terus meningkat, menyebabkan banyak penduduk yang masuk dalam kategori angkatan kerja. Sementara dampak dari peningkatan penduduk yang cepat akan mengurangi pendapatan, tabungan dan investasi yang membuat pembentukan modal menjadi lambat dan kesempatan kerja semakin sedikit, akibatnya pekerjaan berkurang dan terjadi pengangguran.Pertumbuhan penduduk di Kota Jambi dapat dilihat pada Tabel 1 berikut:

Tabel 1 Pertumbuhan penduduk di Kota Jambi Tahun 2001-2017

\begin{tabular}{cc}
\hline Tahun & $\begin{array}{c}\text { Pertumbuhan Penduduk } \\
(\boldsymbol{\%})\end{array}$ \\
2001 & 1,34 \\
2002 & 1,50 \\
2003 & 1,48 \\
2004 & 1,64 \\
2005 & 1,77 \\
2006 & 1,88 \\
2007 & 1,76 \\
2008 & 1,03 \\
2009 & 1,75 \\
2010 & 1,10 \\
2011 & 0,85 \\
2012 & 1,57 \\
2013 & 1,54 \\
2014 & 1,41 \\
2015 & 1,41 \\
2016 & 1,29 \\
2017 & 1,31 \\
\hline Rata-Rata & $\mathbf{1 , 4 5}$ \\
\hline
\end{tabular}

Sumber : BPS Kota Jambi, 2019(diolah)

Berdasarkan Tabel 1 dapat dilihat bahwa pertumbuhan penduduk di Kota Jambi selama tahun 2001-2017 cenderrung berfluktuasi. Pertumbuhan tertinggi tercatat pada tahun 2006 yaitu 1,88 persen. Tingginya pertumbuhan penduduk pada tahun tersebut disebabkan banyaknya penduduk pindahan dari kabupaten ke Kota Jambi untuk mencari pekerjaan karena di Kota Jambi kesempatan kerja lebih besar karena lapangan kerja yang luas dibandingkan kabupaten/kota lain di Provinsi Jambi, oleh sebab itu Kota Jambi menjadi tempat berkumpulnya penduduk lain mencari kerja dan menetap di Kota Jambi. Sedangkan pertumbuhan penduduk terendah tercatat pada tahun 2011 yaitu sebesar 0,85 persen, rendahnya pertumbuhan penduduk pada tahun 2011 disebabkan menurunnya angka kelahiran di Kota Jambi.

Jika rata-rata pertumbuhan penduduk Kota Jambi dibandingkan dengan Provinsi Jambi dan Indonesia, maka rata-rata pertumbuhan penduduk Kota Jambi lebih kecil dari pertumbuhan penduduk Provinsi Jambi dengan rata-rata pertumbuhan penduduk di Provinsi Jambi yaitu sebesar 2,18 persen dan juga lebih kecil dari rata-rata pertumbuhan penduduk Indonesia yaitu sebesar 1,42 persen. 


\section{Perkembangan inflasi}

Inflasi adalah kecenderungan akan naiknya harga barang-barang secara umum, yang berarti terjadinya penurunan nilai uang. Penyebab utama dan satu-satunya yang memungkinkan gejala ini muncul menurut teori kuantitas adalah terjadinya kelebihan uang yang beredar sebagai akibat penambahan jumlah uang di masyarakat (Rimsky, 2002). Untuk melihat perkembangan inflasi di Kota Jambi dapat kita lihat pada Tabel 2. Berdasarkan tabel 2 dapat dilihat bahwa selama tahun 2001-2017 inflasi berfluktuasi setiap tahunnya. Rata-rata inflasi dari tahun 2001-2017 yaitu sebesar 5,73 persen, artinya inflasi Kota Jambi berada pada tingkat 5,73 persen setiap tahunnya. Inflasi tertinggi tercatat pada tahun 2005 yaitu sebesar 16,50 persen, angka inflasi ini tertinggi selama periode 2001-2017. Tingginya inflasi yang terjadi pada tahun 2005 terjadi disebabkan tingginya pertumbuhan penduduk yaitu sebesar 2,27 persen, tingginya pertumbuhan penduduk akan menyebabkan permintaan suatu barang dan jasa melonjak tinggi dan permintaan tersebut tidak dapat terpenuhi akibat keterbatasan barang dan jasa yang diminta, sehingga harga melonjak naik dan terjadilah peningkatan inflasi yang signifikan. Sedangkan inflasi terendah tercatat pada tahun 2013 yaitu sebesar 1,04 persen, rendahnya inflasi tersebut terjadi karena pada tahun tersebut pemerintah pusat dan daerah mampu menjaga stabilitas harga pada sejumlah komoditas seperti beras, cabe, daging, bawang dan kebutuhan pokok makanan inflasinya terkendali dengan baik.

Tabel 2 Perkembangan inflasi di Kota Jambi Tahun 2001-2017

\begin{tabular}{cc}
\hline Tahun & $\begin{array}{c}\text { Inflasi } \\
(\boldsymbol{\%})\end{array}$ \\
\hline 2001 & 7,58 \\
2002 & 4,79 \\
2003 & 4,30 \\
2005 & 7,25 \\
2006 & 16,50 \\
2007 & 10,66 \\
2008 & 2,75 \\
2009 & 11,57 \\
2010 & 2,49 \\
2011 & 6,31 \\
2012 & 3,22 \\
2013 & 2,62 \\
2014 & 1,04 \\
2015 & 8,72 \\
2016 & 1,37 \\
2017 & 3,92 \\
Rata-Rata & 2,32 \\
\hline
\end{tabular}

Sumber : Bank Indonesia, 2019

Jika rata-rata inflasi Kota Jambi dibandingkan dengan Provinsi Jambi dan Indonesia, maka rata-rata inflasi Kota Jambi lebih besar dari inflasi Provinsi Jambi dengan rata-rata inflasi di Provinsi Jambi yaitu sebesar 2,18 persen dan juga lebih besar dari inflasi Indonesia yaitu sebesar 5,12 persen. 


\section{Perkembangan investasi}

Investasi adalah kegiatan mengalokasikan atau menanamkan sumber daya (resorce) saat ini (sekarang), dengan harapan mendapatkan manfaat dikemudian hari (masa datang). Investasi dilakukan untuk memenuhi berbagai kebutuhan masyarakat baik individu, kelompok, dan bahkan negara. Untuk melihat perkembangan investasi di Kota Jambi dapat kita lihat pada Tabel 3. Berdasarkan tabel 3 dapat dilihat perkembangan investasi di Kota Jambi tahun 2001-2017 mengalami fluktuasi. Rata-rata perkembangan investasi di Kota Jambi selama tahun 2001 sampai tahun 2017 yaitu sebesar 8,55 persen, artinya perkembangan investasi di Kota Jambi setiap tahunnya mengalami peningkatan selama tahun 2001-2017 sebesar 8,55 persen.

Tabel 3 Perkembangan investasi di Kota Jambi Tahun 2001-2017

\begin{tabular}{ccc}
\hline Tahun & Investasi (Rp. Milyar) & Perkembangan $(\boldsymbol{\%})$ \\
\hline 2001 & 876 & - \\
2002 & 987 & 12,67 \\
2003 & 1.048 & 6,18 \\
2004 & 1.094 & 4,39 \\
2005 & 1.126 & 2,93 \\
2006 & 1.374 & 22,02 \\
2007 & 1.252 & $-8,88$ \\
2008 & 1.313 & 4,87 \\
2009 & 1.376 & 4,80 \\
2010 & 1.428 & 3,78 \\
2011 & 1.501 & 5,11 \\
2012 & 1.418 & $-5,53$ \\
2013 & 1.923 & 35,61 \\
2014 & 2.472 & 28,55 \\
2015 & 2.368 & $-4,21$ \\
2016 & 2.528 & 6,76 \\
2017 & 2.978 & 17,80 \\
\hline Rata-Rata & 1.592 & 8,55 \\
\hline
\end{tabular}

Sumber : Dinas Penanaman Modal dan PTSP, 2019(diolah)

Perkembangan investasi tertinggi terjadi pada tahun 2013 dengan peningkatan yang signifikan dari tahun sebelumnya yaitu sebesar 35,61 persen dengan investasi sebesar Rp. 1.923 milyar dari investasi sebelumnya yaitu Rp. 1.418 milyar, peningkatan ini terjadi disebabkan banyaknya investor menanamkan modalnya pada sektor perdagangan hotel dan restoran pada saat itu, misalnya Hotel Aston, Hotel Luminore, gerai-gerai Alfamart dan Indomaret, total terdapat 19 perusahaan yang telah melakukan investasi padatahun 2013. Sedangkan penurunan penerimaan investasi terjadi pada tahun 2007 dengan penurunan sebesar -8,88 persen dari tahun sebelumnya. Penurunan investasi tersebut disebabkan pada tahun 2006 inflasi mengalami kenaikan menjadi sebesar 8,88 persen, sehingga tingkat inflasi yang tinggi akan meningkatkan resiko proyek-proyek investasi dan dalam jangka panjang inflasi yang tinggi dapat mengurangi rata-rata masa jatuh pinjam modal serta menimbulkan distorsi informasi tentang harga-harga relatif. Jika rata-rata perkembangan investasi Kota Jambi dibandingkan dengan Provinsi 
Jambi dan Indonesia, maka rata-rata perkembangan investasi Kota Jambi lebih kecil dari perkembangan investasi Provinsi Jambi dengan rata-rata perkembangan investasi di Provinsi Jambi yaitu sebesar 12,08 persen dan namun lebih lebih besar dari perkembangan investasi Indonesia yaitu sebesar 7,78 persen.

\section{Perkembangan upah minimum}

Berdasarkan Peraturan Menteri Tenaga Kerja dan Transmigrasi Nomor 7 Tahun 2013 tentang Upah Minimum bahwa Upah Minimum adalah upah minimum yang berlaku untuk seluruh kabupaten/ kota di satu provinsi. Upah minimum adalah upah bulanan terendah yang terdiri atas upah pokok termasuk tunjangan tetap yang ditetapkan oleh gubernur sebagai jaring pengaman. Kota Jambi memakai standar upah yang sama dengan kabupaten/kota lainnya yang ada di Provinsi Jambi. Berikut ini tabel perkembangan upah minimum Kota Jambi selama tahun 2001-2017:

Tabel 4 Perkembangan upah minimum Kota Jambi Periode 2001-2017

\begin{tabular}{ccc}
\hline Tahun & UMP Ribu Rupiah) & Perkembangan $(\boldsymbol{\%})$ \\
\hline 2001 & 245 & - \\
2002 & 304 & 24,08 \\
2003 & 390 & 28,29 \\
2004 & 425 & 8,97 \\
2005 & 485 & 14,12 \\
2006 & 563 & 16,08 \\
2007 & 658 & 16,87 \\
2008 & 724 & 10,03 \\
2009 & 800 & 10,5 \\
2010 & 900 & 12,5 \\
2011 & 1.028 & 14,22 \\
2012 & 1.142 & 11,14 \\
2013 & 1.300 & 13,79 \\
2014 & 1.502 & 15,56 \\
2015 & 1.710 & 13,83 \\
2016 & 1.906 & 11,5 \\
2017 & 2.063 & 8,20 \\
\hline Rata-Rata & & $\mathbf{1 4 , 3 6}$ \\
\hline
\end{tabular}

Sunber : BPS Kota Jambi, 2019

Berdasarkan Tabel 4 upah minimum di Kota Jambi terus mengalami peningkatan setiap tahunnya, namun perkembangannya masih berfluktuasi. Rata-rata perkembangan upah minimum Kota Jambi selama tahun 2001-2017 yaitu sebesar 14,36 persen. Artinya upah minimum di Kota Jambi mengalami peningkatan sebesar 14,36 persen setiap tahunnya.

Perkembangan upah minimum tertinggi tercatat pada tahun 2003 dengan perkembangan upah minimum sebesar 28,29 persen. Pada tahun 2003 upah minimum yang ditetapkan sebesar Rp.304 ribu, nilai upah minimum ini naik dari tahun sebelumnya 
sebesar Rp. 86 ribu. Sementara perkembangan terendah tercatat pada tahun 2017 yaitu sebesar 8,20 persen. Pada tahun 2017 upah minimum yang ditetapkan sebesar Rp.2.063 hanya naik dari tahun sebelumnya sebesar Rp. 156 ribu. Rendahnya perkembangan tersebut disebabkan oleh keputusan Pemerintah Provinsi Jambi berdasarkan pertimbangan asumsi inflasi di Jambi sebesar 3,07 persen dan pertumbuhan ekonomi tahun 2017 sebesar 5,1 persen. Peningkatan upah minimum tentunya akan terus terjadi setiap tahunnya berdasarkan Peraturan Pemerintahan Nomor 78 tahun 2015 dengan tujuan untuk mensejahterakan para pekerja.

\section{Perkembangan kesempatan kerja}

Kesempatan kerja adalah suatu keadaan yang menggambarkan ketersediaan pekerjaan untuk diisi oleh para pencari kerja. Namun bisa diartikan juga sebagai permintaan atas tenaga kerja. Berikut ini tabel perkembangan kesempatan kerja Kota Jambi selama tahun 2001-2017

Tabel 5. Perkembangan kesempatan kerja di Kota Jambi Tahun 2001-2017

\begin{tabular}{ccc}
\hline Tahun & $\begin{array}{c}\text { Kesempatan Kerja } \\
\text { (Ribu Orang) }\end{array}$ & $\begin{array}{c}\text { Perkembangan } \\
(\boldsymbol{\%})\end{array}$ \\
\hline 2001 & 142 & - \\
2002 & 149 & 4,93 \\
2003 & 153 & 2,68 \\
2004 & 160 & 4,58 \\
2005 & 166 & 3,75 \\
2006 & 171 & 3,01 \\
2007 & 176 & 2,92 \\
2008 & 191 & 8,52 \\
2009 & 195 & 2,09 \\
2010 & 218 & 11,79 \\
2011 & 238 & 9,17 \\
2012 & 226 & $-5,04$ \\
2013 & 230 & 1,77 \\
2014 & 235 & 2,17 \\
2015 & 254 & 8,09 \\
2016 & 259 & 1,97 \\
2017 & 268 & 3,47 \\
\hline Rata-rata & & $\mathbf{4 , 1 2}$ \\
\hline
\end{tabular}

Sumber : BPS Provinsi Jambi, 2019(diolah)

Dapat dilihat pada Tabel 5. mengenai kesempatan kerja di Kota Jambi tahun 20012017, dimana perkembangannya selama tujuh belas tahun terakhir berkembang dengan berfluktuasi. Jika dilihat secara rata-rata perkembangan kesempatan kerja selama tujuh belas tahun terakhir sebesar 4,12 persen, artinya secara rata-rata ketersediaan pekerjaan di Kota Jambi meningkat setiap tahunnya sebesar 4,12 persen. Perkembangan kesempatan kerja tertinggi di Kota Jambi tercatat pada tahun 2010 yaitu meningkat sebesar 11,79 persen dari tahun sebelumnya dengan jumlah ketersediaan pekerjaan sebanyak 195 ribu jiwa di tahun 2009 menjadi 218 ribu jiwa di tahun 2010. Tingginya peningkatan 
kesempatan kerja pada tahun tersebut disebabkan banyaknya perusahaan perusahaan yang baru berdiri di Kota Jambi dan beberapa mall seperti WTC dan Jamtos serta beberapa perusahaan perbankan dan lembagai pembiayaan keuangan membuka lapangan kerja secara besar-besaran.

Kesempatan kerja di Kota Jambi juga mengalami penurunan dalam tujuh belas tahun terakhir, dimana tercatat pada tahun 2012 penurunan jumlah kesempatan kerja sebesar -5,04 persen dengan jumlah ketersediaan pekerjaan sebanyak 238 ribu jiwa di tahun 2011 dan turun di tahun 2012 menjadi 226 ribu jiwa. Penurunan kesempatan kerja ini disebabkan beberapa perusahaan besar di Kota Jambi mengurangi karyawannya untuk mengurangi beban biaya pada sektor gaji, serta adanya beberapa perusahaan pembiayaan keuangan yang gulung tikar salah satunya seperti Bank Permata. Kondisi ketenagakerjaan tersebut semestinya menjadi perhatian pemerintah daerah Kota Jambi, mengingat bahwa sumberdaya manusia sangat penting perannya dalam pembangunan.

\section{Perkembangan pengangguran}

Pengangguran merupakan salah satu masalah utama dalam jangka pendek yang selalu dihadapi setiap negara. Karena itu, setiap perekonomian dan negara pasti menghadapi masalah pengangguran, yaitu pengangguran alamiah (natural rate of unemployment). Berikut ini tabel perkembangan pengangguran Kota Jambi selama tahun 2001-2017:

Tabel 6. Perkembangan pengangguran di Kota Jambi Tahun 2001- 2017

\begin{tabular}{ccc}
\hline Tahun & $\begin{array}{c}\text { Pengangguran } \\
\text { (Ribu Orang) }\end{array}$ & $\begin{array}{c}\text { Perkembangan } \\
(\boldsymbol{\%})\end{array}$ \\
\hline 2001 & 9.138 & - \\
2002 & 9.622 & 5,30 \\
2003 & 9.812 & 1,97 \\
2004 & 10.544 & 7,46 \\
2005 & 11.957 & 13,40 \\
2006 & 12.284 & 2,73 \\
2007 & 13.581 & 10,56 \\
2008 & 14.710 & 8,31 \\
2009 & 16.411 & 11,56 \\
2010 & 18.535 & 12,94 \\
2011 & 18.907 & 2,01 \\
2012 & 17.657 & $-6,61$ \\
2013 & 18.518 & 4,88 \\
2014 & 20.569 & 11,08 \\
2015 & 20.098 & $-2,29$ \\
2016 & 18.276 & $-9,07$ \\
2017 & 15.754 & $-13,80$ \\
\hline Rata-rata & & $\mathbf{3 , 7 8}$ \\
\hline
\end{tabular}

Sumber : BPS Provinsi Jambi, 2019(diolah)

Dapat dilihat pada Tabel 6 mengenai pengangguran di Kota Jambi tahun 20012017, dimana perkembangannya selama tujuh belas tahun terakhir berkembang dengan berfluktuasi. Jika dilihat secara rata-rata perkembangan pengangguran selama tujuh belas 
tahun terakhir sebesar 3,78 persen, artinya secara rata-rata pengangguran di Kota Jambi meningkat setiap tahunnya sebesar 3,78 persen. Perkembangan pengangguran tertinggi di Kota Jambi tercatat pada tahun 2005 yaitu meningkat sebesar 13,40 persen dari tahun sebelumnya dengan pengangguran sebanyak 10.544 ribu jiwa di tahun 2004 menjadi 11.957 ribu jiwa di tahun 2005. Tingginya peningkatan pengangguran pada tahun tersebut disebabkan tingginya pertumbuhan penduduk yang tidak diimbangi dengan besarnya peningkatan kesempatan kerja.

Pengangguran di Kota Jambi juga mengalami penurunan dalam tujuh belas tahun terakhir, dimana penurunan tertinggi tercatat pada tahun 2017 dengan penurunan pengangguran sebesar $-13,80$ persen jumlah pengangguran sebanyak 18.276 ribu jiwa di tahun 2016 dan turun di tahun 2017 menjadi 15.574 ribu jiwa. Penurunan pengangguran kerja ini disebabkan beberapa perusahaan besar di Kota Jambi membuka kesempatan kerja secara besar-besaran dan penerimaan calon pegawai negeri sipil (CPNS) oleh pemerintah Kota Jambi, sehingga pengangguran dapat dikurangi. Jika rata-rata perkembangan pengangguran Kota Jambi dibandingkan dengan Provinsi Jambi dan Indonesia, maka rata-rata perkembangan pengangguran Kota Jambi lebih kecil dari perkembangan pengangguran Provinsi Jambi dengan rata-rata perkembangan pengangguran di Provinsi Jambi yaitu sebesar 312,08 persen dan namun lebih lebih besar dari perkembangan pengangguran Indonesia yaitu sebesar -3,04 persen.

\section{Pengaruh pertumbuhan penduduk, inflasi, investasi, upah minimum dan kesempatan ker.ja terhadap pengangguran}

Analisis regresi digunakan untuk tujuan peramalan, dimana dalam model tersebut ada sebuah variabel dependen (tergantung) dan variabel independen (bebas). Berdasarkan hasil regresi yang dilakukan dengan menggunakan SPSS. 20, maka hasil regresi adalah :

Tabel 7 Hasil regresi pengaruh pertumbuhan penduduk, inflasi, investasi, upah minimum dan kesempatan kerja terhadap pengangguran di Kota Jambi

\begin{tabular}{|c|c|c|c|c|c|c|c|c|}
\hline \multicolumn{9}{|c|}{ Coefficients $^{\mathrm{a}}$} \\
\hline \multirow{2}{*}{\multicolumn{2}{|c|}{ Model }} & \multicolumn{2}{|c|}{$\begin{array}{l}\text { Unstandardized } \\
\text { Coefficients }\end{array}$} & \multirow{2}{*}{$\begin{array}{c}\begin{array}{c}\text { Standardized } \\
\text { Coefficients }\end{array} \\
\text { Beta }\end{array}$} & \multirow{2}{*}{$\mathbf{t}$} & \multirow{2}{*}{ Sig. } & \multicolumn{2}{|c|}{$\begin{array}{c}\text { Collinearity } \\
\text { Statistics }\end{array}$} \\
\hline & & B & $\begin{array}{l}\text { Std. } \\
\text { Error }\end{array}$ & & & & $\begin{array}{c}\text { Toleranc } \\
\text { e }\end{array}$ & VIF \\
\hline \multirow{6}{*}{1} & (Constant) & $-23,364$ & 9,970 & & $-2,343$ & ,039 & & \\
\hline & $\mathrm{PP}$ & 2,303 & 1,789 &, 164 & 1,287 & ,224 & ,648 & 1,542 \\
\hline & INF &, 031 &, 117 &, 033 & ,261 & ,799 & 672 & 1,488 \\
\hline & INV &, 002 &, 004 &, 260 & ,446 & ,664 &, 031 & 2,149 \\
\hline & UM &,- 011 & ,007 & $-1,556$ & $-1,566$ & , 146 &, 011 & 3,386 \\
\hline & KK & 210 &, 052 & 2,244 & 4,034 &, 002 & 034 & 9,254 \\
\hline
\end{tabular}

a. Dependent Variable: PG

Sumber : Data diolah, 2020(diolah)

Adapun persamaan regresi linier berganda yaitu sebagai berikut:

$$
P G=\beta_{0}+2,303 P P+0,031 I N F+0,002 I N V-0,011 \mathrm{UM}+0,210 \mathrm{KK}+\mathrm{e}
$$

\section{Uji statistik}

\section{Uji simultan}

Uji F digunakan untuk mengetahui apakah variabel-variabel independen secara bersama-sama berpengaruh terhadap variabel dependen. Pengujian dilakukan dengan menggunakan signifikansi level 0,05 $(\alpha=5 \%)$. Untuk menguji pengaruh antara variabel 
bebas (variabel independen) terhadap variabel terikat (variabel dependen) secara simultan digunakan alat uji F statistik yang dapat dilihat pada hasil output program SPSS 20 pada tabel ANNOVA sebagai berikut :

Tabel 8 Hasil uji F Statistik

\begin{tabular}{|c|c|c|c|c|c|c|}
\hline \multicolumn{7}{|c|}{$\mathrm{ANOVA}^{\mathrm{a}}$} \\
\hline & Model & Sum of & df & Mean Square & $\mathbf{F}$ & Sig. \\
\hline \multirow{3}{*}{1} & Regression & 217,534 & 5 & 43,507 & 16,711 &, $000^{\mathrm{b}}$ \\
\hline & Residual & 28,638 & 11 & 2,603 & & \\
\hline & Total & 246,172 & 16 & & & \\
\hline
\end{tabular}

a. Dependent Variable: PG

b. Predictors: (Constant), KK, PP, INF, INV, UM

Sumber : Data diolah, 2020

Berdasarkan hasil regresi diketahui atau diperoleh signifikansi F-sig sebesar 0,001 lebih kecil dari 0,05. Artinya Ho ditolak dan Ha diterima, hal ini dapat diartikan bahwa variabel bebas (pertumbuhan penduduk, inflasi, investasi, upah minimum dan kesempatan kerja) secara bersama-sama (simultan) berpengaruh signifikan terhadap variabel terikat (pengangguran) di Kota Jambi selama periode 2001-2017.

\section{Uji parsial}

Uji statistik merupakan pengujian secara parsial yang bertujuan untuk mengetahui apakah masing-masing koefisien regresi signifikan atau tidak terhadap variabel dependent dengan menganggap variabel lainnya konstan. Untuk melihat hasil setiap variabel terikat secara parsial yang diuji dengan uji-t secara rinci koefisien regresi pada setiap variabel dapat dilihat pada tabel 5.7 yang menunjukkan hasil sebagai berikut :

\section{Variabel pertumbuhan penduduk}

Dari hasil pengujian diperoleh nilai probabilita untuk variabel pertumbuhan penduduk sebesar 0,224. dengan tingkat keyakinan $(\alpha=5 \%)$, dari perhitungan tersebut dapat dilihat bahwa nilai probabilita lebih besar dari alpha $(0,224>0,05)$, artinya Ho diterima dan Ha ditolak artinya pertumbuhan penduduk tidak berpengaruh signifikan terhadap pengangguran di Kota Jambi.

\section{Variabel inflasi}

Dari hasil pengujian diperoleh nilai probabilita untuk variabel Inflasi sebesar 0,799. dengan tingkat keyakinan $(\alpha=5 \%)$, dari perhitungan tersebut dapat dilihat bahwa nilai probabilita lebih besar dari alpha $(0,799>0,05)$, artinya Ho diterima dan Ha ditolak artinya inflasi tidak berpengaruh signifikan terhadap pengangguran di Kota Jambi.

\section{Variabel investasi}

Dari hasil pengujian diperoleh nilai probabilita untuk variabel investasi sebesar 0,664. dengan tingkat keyakinan $(\alpha=5 \%)$, dari perhitungan tersebut dapat dilihat bahwa nilai probabilita lebih besar dari alpha $(0,664>0,05)$, artinya Ho diterima dan Ha ditolak artinya investasi tidak berpengaruh signifikan terhadap pengangguran di Kota Jambi. 


\section{Variabel upah minimum}

Dari hasil pengujian diperoleh nilai probabilita untuk variabel upah minimum sebesar 0,146 . dengan tingkat keyakinan $(\alpha=5 \%)$, dari perhitungan tersebut dapat dilihat bahwa nilai probabilita lebih besar dari alpha $(0,146>0,05)$, artinya Ho diterima dan Ha ditolak artinya upah minimum tidak berpengaruh signifikan terhadap pengangguran di Kota Jambi.

\section{Variabel kesempatan kerja}

Dari hasil pengujian diperoleh nilai probabilita untuk variabel kesempatan kerja sebesar 0,002 , dengan tingkat keyakinan $(\alpha=5 \%)$, dari perhitungan tersebut dapat dilihat bahwa nilai probabilita lebih besar dari alpha $(0,002<0,05)$, artinya Ho ditolak dan Ha diterima artinya kesempatan kerja berpengaruh signifikan terhadap pengangguran di Kota Jambi.

\section{Uji determinan}

Analisis koefisiensi determinasi (KD) digunakan untuk melihat beberapa besar variabel bebas berpengaruh terhadap variabel terikat yang dinyatakan dalam persentase. Seperti yang ditunjukkan pada tabel berikut :

Tabel 9. Hasil uji $\mathrm{R}^{2}$ Square

\begin{tabular}{|c|c|c|c|c|c|c|c|c|c|}
\hline \multicolumn{10}{|c|}{ Model Summary } \\
\hline \multirow[t]{2}{*}{$\mathbf{R}$} & \multirow{2}{*}{$\begin{array}{c}\mathbf{R} \\
\text { Square }\end{array}$} & \multirow{2}{*}{$\begin{array}{l}\text { Adjusted } \\
\text { R Square }\end{array}$} & \multirow{2}{*}{$\begin{array}{l}\text { Std. Error } \\
\text { of the } \\
\text { Estimate }\end{array}$} & \multicolumn{5}{|c|}{ Change Statistics } & \multirow{2}{*}{$\begin{array}{l}\text { Durbin- } \\
\text { Watson }\end{array}$} \\
\hline & & & & $\begin{array}{l}\text { R Square } \\
\text { Change }\end{array}$ & $\begin{array}{c}\text { F } \\
\text { Change }\end{array}$ & df1 & df2 & $\begin{array}{c}\text { Sig. F } \\
\text { Change }\end{array}$ & \\
\hline ,940 & ,884 & ,831 & 1,61353 & ,884 & 16,711 & 5 & 11 & ,000 & 1,156 \\
\hline
\end{tabular}

Sumber : Data Diolah, 2020

Tabel 9 diatas dapat dilihat model summary diketahui nilai $\mathrm{R}_{\text {square }}$ sebesar 0,884 . Artinya sebesar 88,4 persen variasi pengangguran dijelaskan oleh variabel bebas dalam model, sedangkan sisanya 11,6 persen dijelaskan oleh variabel lain diluar penelitian.

\section{Analisis ekonomi}

Berdasarkan hasil regresi diketahui bahwa kesempatan kerja berpengaruh signifikan terhadap pengangguran, dengan nilai koefisien sebesar 0,10 , artinya artinya bila terjadi peningkatan ksempatan kerja sebanyak seribu orang maka pengangguran di Kota Jambi akan meningkat sebesar 0,210 ribu orang. Hasil ini belum sependapat dengan teori yang dikemukakan oleh Sukirno (2004) yang mengatakan mengurangi pengangguran dengan cara memperluas kesempatan kerja dengan membuka lapangan kerja baru, melakukan pemindahan tenaga kerja yang kelebihan ke tenaga kerja yang kurang sehingga bisa menyeimbangi, memberikan informasi lowongan kerja yang ada, melakukan pelatihan tenaga kerja kepada orang-orang sehingga mereka siap untuk terjun langsung ke lapangan.

Kondisi yang terjadi saat ini pengangguran di Kota Jambi mengalami perkembangan yang positif bukannya negatif. Peningkatan kesempatan kerja diirngi dengan pengangguran yang meningkat juga dikarenakan kesempatan kerja tidak sekuruhnya menyerap tenaga kerja dari tenga kerja di Kota Jambi, melainkan juga 
menyerap dari wilayah lain bahkan luar negeri. Sehingga peningkatan kesempatan kerja tidak mampu mengimbangi peningkatan jumlah angkatan kerja di Kota Jambi dan berdampak pada meningkatnya pengangguran. Seharusnya pihak pemerintah dan swasta mendahului penduduk berdomisili di Kota Jambi dalam penyerapan tenaga kerja.

\section{KESIMPULAN DAN SARAN}

\section{Kesimpulan}

Berdasarkan laju pertumbuhan penduduk di Kota Jambi selama tahun 2001-2017 cenderung berfluktuasi dengan rata-rata perkembangan sebesar 1,45 persen. Selanjutnya inflasi berfluktuasi setiap tahunnya dengan rata-rata inflasi dari tahun 2001-2017 yaitu sebesar 5,73 persen. Kemudian perkembangan investasi di Kota Jambi tahun 2001-2017 mengalami fluktuasi dengan rata-rata perkembangan sebesar 8,55 persen. Selanjutnya upah minimum di Kota Jambi terus mengalami peningkatan setiap tahunnya, namun perkembangannya masih berfluktuasi dengan rata-rata perkembangan upah minimum sebesar 14,36 persen. Selanjutnya perkembangan kesempatan kerja selama tujuh belas tahun terakhir berkembang dengan berfluktuasi dengan rata-rata perkembangan sebesar 4,12 persen. Terakhir mengenai pengangguran di Kota Jambi tahun 2001-2017, dimana perkembangannya selama tujuh belas tahun terakhir berkembang dengan berfluktuasi dengan rata-rata perkembangan sebesar 3,78 persen. Berdasarkan hasil regresi linier berganda dapat disimpulkan bahwa yang berpengaruh terhadap penganguran hanya variabel kesempatan kerja.

\section{Saran}

Pemerintah Kota Jambi harus menurunkan pengangguran setiap tahunnya dengan membuat kebijakan terhadap pemanfaatan meningkatnya pertumbuhan penduduk, inflasi, investasi, upah minimum dan kesempatan kerja agar memiliki dampak terhadap pengurangan pengangguran. Pemerintah Kota Jambi seharusnya dapat meningkatkan atau memperluas kesempatan kerja dengan sebesar-besarnya untuk tenaga kerja yang belum mendapat pekerjaan, salah satunya dengan menarik investor dan membuka penerimaan CPNS agar terbukanya lapangan kerja yang akan mengurangi pengangguran.

\section{DAFTAR PUSTAKA}

Anwar, Sanus. (2011). Metode Penelitian Bisnis, Salemba Empat: Jakarta

Bank Indonesia (2018). Inflasi di Kota Jambi selama tahun 2001-2017. diakses dalam http://bi.go.id, Tanggal 12 Februari 2018, Pukul 08.30 WIB..

BPS.(2018).Pertumbuhan Penduduk, Upah Minimum Kesempatan Kerja dan Pengangguran di Kota Jambi selama tahun 2001-2017. Provinsi Jambi dalam Angka: Jambi

Dinas Penanaman Modal dan Pelayanan Terpadu Satu Pintu, (2018). Investasi di Kota Jambi selama tahun 2001-2017

Dornbusch, Rudiger, Stanley Fisher, Richard Startz.(2007). Makroekonomi, Edisi Bahasa Indonesia. Terjemahan Yusuf dan Roy Indra Mirazudin. PT. Media Global Edukasi: Jakarta

Dumairy. (1997). Perekonomian Indonesia, Erlangga: Jakarta 
Fusfeld. (1993). Microeconomic Theory A Mathematical Approach Third Edition. (Benyamin Molan, Pentj) Singapore, Mc Graw - Hill International Book Co: Singapore.

Kaufman, dan Julie Hotchkiss, (1999). The Economics Of Labor Market, Fifth Edition. The Dryden Press.

Mankiw Gregory, (2006). Pengantar Ekonomi Makro, Edisi Ketiga, Salemba Empat: Jakarta.

Mulyadi, A., Hardiani,H., \& Umiyati, E. (2017). Faktor-faktor yang mempengaruhi penyerapan tenaga kerja pada sektor industri kecil di Kabupaten Muaro Jambi. e-Jurnal Perdagangan Industri dan Moneter, 6 (1), 35-44

Sukirno, Sadono. (2004). Makro Ekonomi Modern. Raja Grafindo Persada: Jakarta

Sukirno, Sadono. (2013). Makro Ekonomi, Teori Pengantar. PT. Raja Grafindo Persada: Jakarta

Sunargo,S., \& Hastuti, D. (2019). Mengatasi perilaku kerja kontraproduktif melalui peran integratif politik organisasional dan kecerdasan emosional pada era revolusi industri 4.0, Jurnal Paradigma Ekonomika 14 (2), 45-54

Syafri, M., \& Zulfanetti, Z. (2018).Analisis Faktor yang Mempengaruhi Penyerapan Tenaga Kerja di Provinsi Jambi. Jurnal Ilmiah Universitas Batanghari Jambi, 18 (1), 77-86

Zamzami, W., Junaidi dan Prihanto, H.P. (2020). Pengaruh belanja modal dan investasi terhadap pertumbuhan ekonomi melalui kesempatan kerja di Provinsi Jambi. Jurnal Paradigma Ekonomika, 15(1), 115 - 124

Zamzami,Z., \& Hastuti, D. (2018). Determinan penerimaan daerah dan pertumbuhan ekonomi terhadap pengembangan ekonomi kreatif di Provinsi Jambi. Jurnal Paradigma Ekonomika, 13 (1), 37-45 